\title{
COMPARISON OF CHEMICAL STRUCTURE OF ALGINITE HUMIC ACIDS ISOLATED WITH TWO DIFFERENT PROCEDURES WITH SOIL HUMIC ACIDS
}

\author{
GABRIELA BARANČÍKOVÁ*, TADEÁŠ LITAVEC \\ National Agriculture and Food Centre - Soil Science and Conservation Research Institute, Bratislava, \\ Slovak Republic
}

BARANČÍKOVÁ, G. - LITAVEC, T.: Comparison of chemical structure of alginite humic acids isolated with two different procedures with soil humic acids. Agriculture (Polnohospodárstvo), vol. 62, 2016, no. 4, pp. 138-148.

The different origin of alginite and soil organic matter may be the reason of differences in their humic acids (HA) chemical structure. One of the aims of this article is to compare the chemical composition of alginite HA and HA isolated from different soil types. Another aim of this article is to compare the chemical structure of humic acids of alginite isolated with two different procedures: modified IHSS (International Humic Substances Society) method and simplified extraction method. The modified IHSS method was applied for the isolation of alginite and soil HA. To obtain sufficient amount of alginate HA for biological experiments, simplified extraction method suited for large volumes of HA was applied. The differences in elemental analysis and ash proportion in HA extracted by modified IHSS method $(\mathrm{C}=35.4, \mathrm{H}=43$ atomic $\%$, ash content $=0.08 \%)$ and simplified extraction method $(\mathrm{C}=31, \mathrm{H}=31$ atomic $\%$, ash content $=7.42 \%$ ) can be caused by different concentration of extraction solution and also differences in purification of HA. The differences in chemical structure between alginate HA and HA isolated from different soil types according to the data of elemental analysis ( $\mathrm{C}$ content of alginite $\mathrm{HA}=35.4$ atomic\%, C content in soils $\mathrm{HA}=38.2-49.1$ atomic\%) and ${ }^{13} \mathrm{C}$ nuclear magnetic resonance (NMR) spectra (degree of aromaticity of alginite $\mathrm{HA}=24.4 \%$ and soil $\mathrm{HA}=$ $35.9-53 \%$ ) were found. Results of ${ }^{13} \mathrm{C}$ NMR show that the content of aromatic carbon was decreasing in the following order: Haplic Chernozem HA $>$ Andic Cambisol HA $>$ Haplic Cambisol HA $>$ alginite HA. Based on the obtained results, it can be concluded that the differences in the chemical structure of alginite and soil HA can be explained by the difference in the origin of organic matter in alginite and soil samples. The source of organic matter in alginite is mainly type II kerogen from algae and that of soil is lignin and cellulose (type III kerogen) of higher plants.

Key words: alginite, ${ }^{13} \mathrm{C}$ NMR spectra, elemental analysis, humic acid, soil

Agricultural intensification that results in deterioration of soil structure and loss of organic matter is one of the main problems nowadays. The implementation of suitable natural materials that are non-toxic and their effect is almost in short time after application could be a chance for the future agriculture. One of such material would be alginite. The name alginite originally belonged to petrographic constituent of coal residues consisting of algae. However, in 1980s, Hungarian author Solti (1987) used this name for dark grey laminated rock with algae occurrence. Alginite is fossil algae created in the Pannonian lakes system. Three to four million years ago, because of volcanic eruptions, algae together with eroded rocks formed continuous sediment (Kulich et al. 2001). Alginite is a natural organo-mineral substance, which in all respects meets the demands of clean and environmentally friendly revitalisation material. This neutral material with high amount of organic matter, balanced proportion of biogenic and trace elements, the absence of risk elements and high sorption capacity has prospective use in agricultural practice (Kulich et al. 2001). This non-toxic material occurs in the south part of Slovakia near Pinciná village and also in Gercei and Pula in Hungary (Kulich et al. 2001; Vass et al. 1997). Alginite

RNDr. Gabriela Barančíková, CSc. (*Corresponding author), Mgr. Tadeáš Litavec, National Agriculture and Food Centre, Soil Science and Conservation Research Institute, Regional working place Prešov, Raymannova 1, 08001 Prešov, Slovak Republic. E-mail: g.barancikova@vupop.sk 
applied to soil is able to improve the granular soil structure and helps in regeneration of soil organic matter. It is promising material that is capable of reclaiming the land without adverse effects. In agriculture, alginite is also able to improve the water and nutrients regime and increasing of soil colloids (Beláček 2006).

In addition to using alginite as a soil improver, we look for other options of its application in agriculture. Currently, we are working on a project to use alginite and humic acids (HA) isolated from alginite for stabilisation of beneficial micro-organisms and for the needs of the development of new forms of beneficial microorganisms as agents to stabilise and harmonise the microenvironment of animals. Alginite and HA isolated from alginite were used as stimulants for beneficial bacteria. Also the effect of alginite and HA isolated from alginite on the microenvironment of the intestine was studied.

Organic matter of alginite is a component of some types of kerogen with a predominance of type II alongside amorphous organic matter (Vass et al. 1997). Main precursors of soil humic substances are plant biopolymers (Tan 2014). Difference in origin of alginite organic matter and soil organic matter can be reason for the differences in chemical composition of one of the main fractions of humus substances - HA.

Generally, for the extraction of HA, various modifications of standard IHSS method are used (Hayes 1985). However, this method is not a very suitable method for the extraction of huge amount of alginite HA that were needed for testing of their biological effect. We tried to develop simplified extraction method suited for large volumes of alginite HA.

This article has two aims, one aim is to compare the chemical composition of alginite HA and HA isolated from different agriculture and forest soil types. Another aim is to compare chemical structure of HA of alginite isolated using two different procedures: modified IHSS method and simplified extraction method suited for large volumes.

\section{MATERIAL AND METHODS}

The alginite samples were taken from the supply, which is located near the Pinciná village in the south part of Slovakia, $\mathrm{x}=-374,479.89$, $y=-1,272,800.02$. GPS coordinates are in a coordinate system S-JTSK Krovak North East.

The main characteristics of alginite are given in Table 1, and detailed description of alginite supply and alginite samples can be found in our previous article (Litavec \& Barančíková 2013).

For the isolation of soil HA, two soil samples were taken from agricultural soils and two samples from forest soils. The modified IHSS method (Barančíková et al. 2011) was applied for the isolation of alginite and soil HA (Method A).

Detail procedure of simplified extraction method suited for large volumes of alginite HA, method B, is as follow: $200 \mathrm{~kg}$ of preliminary drying alginite was mixed with $0.035 \mathrm{M} \mathrm{KOH}$ on the resulting $\mathrm{pH}=8$. Subsequently, $2 \mathrm{~kg}$ of $\mathrm{KOH}$ was added. Concentration of $\mathrm{KOH}$ solution was increased to $0.1 \mathrm{M}$ and the $\mathrm{pH}$ of solution was increased to 11.1. The resulting alkaline supernatant was set into big vessel. To this solution, concentrated $\mathrm{HCl}$ was added until $\mathrm{pH}$ dropped to 2.5 . In this extremely acidic solution, HA were precipitated. The supernatant that remains after the precipitation of HA containing FA was added to next amount of $200 \mathrm{~kg}$ of preliminary drying alginite. Into this solution, 5001 of $0.035 \mathrm{M}$ $\mathrm{KOH}$ was added. Subsequently, $2 \mathrm{~kg}$ of $\mathrm{KOH}$ was added and the concentration was increased to 0.01 M. This alkaline solution was added to precipitate HA. Subsequently, concentrated $\mathrm{HCl}$ was added, and the $\mathrm{pH}$ dropped to 2.24. Sedimentation of HA was accelerated by aeration and 2001 of distilled water was added. Precipitated HA was washed with distilled water.

Both the methods applied for the isolation of alginite HA are based on the same principle: the extraction of humic substances by alkaline solution of hydroxide. Dark brown solution of humic substances is precipitated by concentrated $\mathrm{HCl}$ to $\mathrm{pH}=$ $1-2$. Despite the same principle of extraction of both methods, some differences exist between methods. The first difference is the extraction of humic substances by $\mathrm{NaOH}$ in case of modified IHSS meth$\operatorname{od}(\operatorname{method} \mathrm{A})$ and by $\mathrm{KOH}$ in case of simplified method suited for large volumes (method B). This difference, however, does not cause the differences in quality but in the yield of HA. The yield of HA by the method A was higher in comparison with meth- 
$\mathrm{T}$ a

Organic carbon content [\%] and basic biogenic elements $[\mathrm{mg} / \mathrm{kg}]$ in alginite

\begin{tabular}{|l|c|c|c|c|c|c|c|}
\hline & $\mathrm{C}_{\text {org }}$ & $\mathrm{N}$ & $\mathrm{P}$ & $\mathrm{K}$ & $\mathrm{Ca}$ & $\mathrm{Mg}$ & $\mathrm{Mn}$ \\
\hline Alginite & 7.5 & 3.090 & 440 & 1.550 & 6.889 & 7.157 & 448 \\
\hline
\end{tabular}

$\mathrm{C}_{\text {org }}$ - organic carbon; $\mathrm{N}$ - total nitrogen; $\mathrm{P}$ - available phosphorus; $\mathrm{K}$ - kalium; $\mathrm{Ca}$ - calcium; $\mathrm{Mg}$ - magnesium; $\mathrm{Mn}$ manganese

od B. The differences in elemental analysis and ash proportion in HA can be caused by different concentration of extraction solution and also differences in purification of $\mathrm{HA}$. Isolated raw HA by method A is soluble in $2 \mathrm{M} \mathrm{NaOH}$ and subsequently is precipitated by concentrated $\mathrm{HCl}$ to $\mathrm{pH}=1-2$. Precipitated HA is purified by $0.3 \%$ mixture of $\mathrm{HCl}-\mathrm{HF}(170 \mathrm{ml}$ of $\mathrm{HCl}-\mathrm{HF}$ mixture per $100 \mathrm{~g}$ of alginite) and dialysed against distilled water until chloride free and then it is dried. The purification step $(0.3 \%$ mixture of HCL-HF) is not included in the method B.

Elemental analysis of alginite and soil HA was made by elementary analyser CHN 2400 Perkin-Elmer. ${ }^{13} \mathrm{C}$ NMR spectra were carried out on spectrometer Varian Inova 600 (frequency $150 \mathrm{MHz}$ ). As published by Malcolm (1990), Preston (1996), Enev (2014) and many others, ${ }^{13} \mathrm{C}$ NMR spectroscopy is able to characterise the types of carbon and aromaticity degree of HA samples. Subdivision of the spectrum has been made by the commonly used scheme of Malcolm (1990). The degree of aromaticity of HA was calculated using the formula: $\alpha=\mathrm{C}_{\mathrm{ar}} / \mathrm{C}_{\mathrm{ar}}+\mathrm{C}_{\mathrm{aliph}} \times 100[\%]$. Detailed procedures for the determination of organic carbon, total nitrogen, biogenic elements in alginite, elemental analysis of HA and ${ }^{13} \mathrm{C}$ NMR parameters of HA can be found in the paper titled 'Methods of determining indicators of agrochemical soil properties' (Barančíková et al. 2011)

\section{RESULTS AND DISCUSSION}

Comparison of chemical structure of alginite $H A$ isolated with two different procedures

As it can be seen in Table 2, the biggest differences between HA isolated by method A (HA A) and B (HA B) are in ash content. The ash in HA represent inorganic substances, mainly silica $\left(\mathrm{SiO}_{2}\right)$ (Vass et al. 1997). Whilst HA A contains a minimal amount of ash $(0.08 \%)$, the amount of ash in HA B is significantly higher $(7.42 \%)$. We assume that this is mainly due to the absence of purification step in the method B.

Data of basic biogenic elements in HA A and HA $B$ are substantially different (Table 3 ). The amount of organic carbon, hydrogen and nitrogen in HA A is significantly higher in comparison with HA B (Table 3).

Differences between HA A and HA B are also clear from elemental composition expressed in atomic percentages (Table 4). A number of scientists believe that elemental composition based on the weight percentages cannot be used to explain the molecular structure of humic substances. For the purpose of studying and devising structural formulas for humic substances, they suggest the use of atomic percentage (Tan 2014). Orlov (1985) and Steelink (1985) reported that atomic percentage and atomic ratios are useful as guiders in the identification of different types of humic acids. The greater $\mathrm{C} / \mathrm{H}$ and $\mathrm{C} / \mathrm{O}$ ratios indicate the higher role of the carbon atoms in the composition of molecular structure. Increase in atomic ratio indicates growth of benzenoid fragments and reduced level of aliphatic chains (Orlov \& Grišina 1981). The values of $\mathrm{C} / \mathrm{H}$ ratio less than 1, in HA A and HA B (Table 4), indicate a predominance of aliphatic structures in alginite HA. The low content of carbon and high value of hydrogen, as well as high value of $\mathrm{H} / \mathrm{C}$ ratio in alginite HA, indicate predominance of aliphatic carbon and low humification degree of alginite $\mathrm{HA}$ because Debska et al. (2009) and Rossel et al. (1989) reported that the smaller the $\mathrm{H} / \mathrm{C}$ ratio, the bigger will be degree of humification. 
Significant predominance of aliphatic structures over aromatic condensed cores in alginite HA structure is clear also from ${ }^{13} \mathrm{C}$ NMR spectra (Figures 1 and 2). ${ }^{13} \mathrm{C}$ NMR spectra are significant contribution to deepening structure of HA (Barančíková 2008; Enev et al. 2014). ${ }^{13} \mathrm{C}$ NMR can quantitatively detect different carbon types (carbonyl, carboxyl, aromatic, olephinic, anomer, aliphatic carbon), and for this reason, this spectral technique is very useful to determinate HA chemical structure of different origin.

In ${ }^{13} \mathrm{C}$ NMR spectra of both HA A and HA B, sharp peaks can be seen in spectral region 43-87 ppm (Figures 1 and 2). This region is characteristic for long $-\mathrm{CH}_{2}-$ chains and also for methyl groups $-\mathrm{CH}_{3}$ in spectral region 15-43 ppm (Figure 2). The sharp signal at $75 \mathrm{ppm}$ is typical for carbohydrates (Preston 1996; Schnitzer et al. 2006) and relatively poor signal at $104 \mathrm{ppm}$ is specific for di-O-alkyl carbon of anomeric carbons of polysaccharides (Preston 1996).

Aromatic region of alginite HA is less marked as aliphatic (Figures 1 and 2). Aromatic carbon is situated in 120-135 ppm (Schnitzer et al. 2006), and wide peak at $129 \mathrm{ppm}$ is characteristic for $\mathrm{H}-$ and C-substituted aromats (Preston et al. 1994). Phenolic carbon of HA is in the 145-165 ppm and this area, in comparison with the $\mathrm{C}$ - and $\mathrm{H}$-substituted

$\mathrm{T}$ a

Basic parameters of alginite HA isolated using modified IHSS method (method A) and simplified procedure adjusted for large volumes (method B)

\begin{tabular}{|l|c|c|c|c|}
\hline \multirow{2}{*}{ Alginite HA } & Dry mater & Ash & Moisture & HA \\
\cline { 2 - 5 } & \multicolumn{3}{|c|}{$[\%]$} \\
\hline HA A & 90.57 & 0.08 & 9.43 & 90.50 \\
HA B & 90.57 & 7.42 & 9.43 & 83.16 \\
\hline
\end{tabular}

HA A - alginite humic acids isolated by method A; HA B - alginite humic acids isolated by method B

T

Values of elemental analysis of alginite HA

\begin{tabular}{|l|c|c|c|c|c|c|}
\hline \multirow{2}{*}{ Alginite HA } & \multicolumn{3}{|c|}{$\begin{array}{c}\text { Real sample } \\
\text { Weight [\%] }\end{array}$} & \multicolumn{3}{c|}{ 100\% ash free } \\
& \multicolumn{3}{|c|}{ HA Weight [\%] } \\
\cline { 2 - 7 } & $\mathrm{C}$ & $\mathrm{H}$ & $\mathrm{N}$ & $\mathrm{C}$ & $\mathrm{H}$ & $\mathrm{N}$ \\
\hline HA A & 47.20 & 5.85 & 2.96 & 52.16 & 5.29 & 3.27 \\
HA B & 30.86 & 3.68 & 1.62 & 37.11 & 3.15 & 1.94 \\
\hline
\end{tabular}

HA A - alginite humic acids isolated by method A; HA B - alginite humic acids isolated by method B; $\mathrm{C}$ - carbon; $\mathrm{H}$ - hydrogen; $\mathrm{N}$ - nitrogen

T

Elemental analysis [atomic\%] and proportion of individual elements

\begin{tabular}{|c|c|c|c|c|c|c|c|c|c|}
\hline \multirow{2}{*}{ Alginite HA } & \multicolumn{10}{|c|}{ Atomic\%] } \\
\cline { 2 - 11 } & $\mathrm{C}$ & $\mathrm{H}$ & $\mathrm{N}$ & $\mathrm{O}$ & $\mathrm{H} / \mathrm{C}$ & $\mathrm{O} / \mathrm{C}$ & $\mathrm{O} / \mathrm{H}$ & $\mathrm{C} / \mathrm{H}$ & $\mathrm{C} / \mathrm{O}$ \\
\hline HA A & 36.36 & 42.75 & 1.90 & 19.99 & - & - & 0.468 & 0.83 & 1.77 \\
HA B & 31.00 & 31.35 & 1.39 & 36.26 & 1.012 & 1.170 & 1.158 & 0.99 & 0.86 \\
\hline
\end{tabular}

HA A - alginite humic acids isolated by method A; HA B - alginite humic acids isolated by method B; $\mathrm{C}$ - carbon; $\mathrm{H}$ - hydrogen; $\mathrm{N}$ - nitrogen; $\mathrm{O}$ - oxygen 
aromats, is often weak and broad and indicates the presence of the phenolic carbon of various origin (Gonzales-Perez et al. 2008). At 175 ppm, significant carbon peak characterising carboxyl, amides and esters (Preston et al. 1994; Schnitzer et al. 2006) can be found. Signal of carboxylic carbon is corresponding with carboxylic groups in aliphatic and benzenecarboxylic acids (Gonzales-Perez et al. 2008). The absence of sharp peaks in aromatic regions is evident in both alginite HA (Figures 1 and 2).
From the HA chemical structure point of view, the most important ${ }^{13} \mathrm{C}$ NMR parameters are the percentage of aliphatic and aromatic carbon and degree of aromaticity $(\alpha)$. In both HA isolates from alginite, percentage of aliphatic carbon is much higher as aromatic carbon (Table 5). The degree of aromaticity, which is the most common parameter to assess the degree of humification (Gonzales-Perez et al. 2008), is reported in most of the works that evaluated the chemical structure of HA based on the ${ }^{13} \mathrm{C}$ NMR spectroscopy (Malcolm1990; Schnitzer et al. 2006;

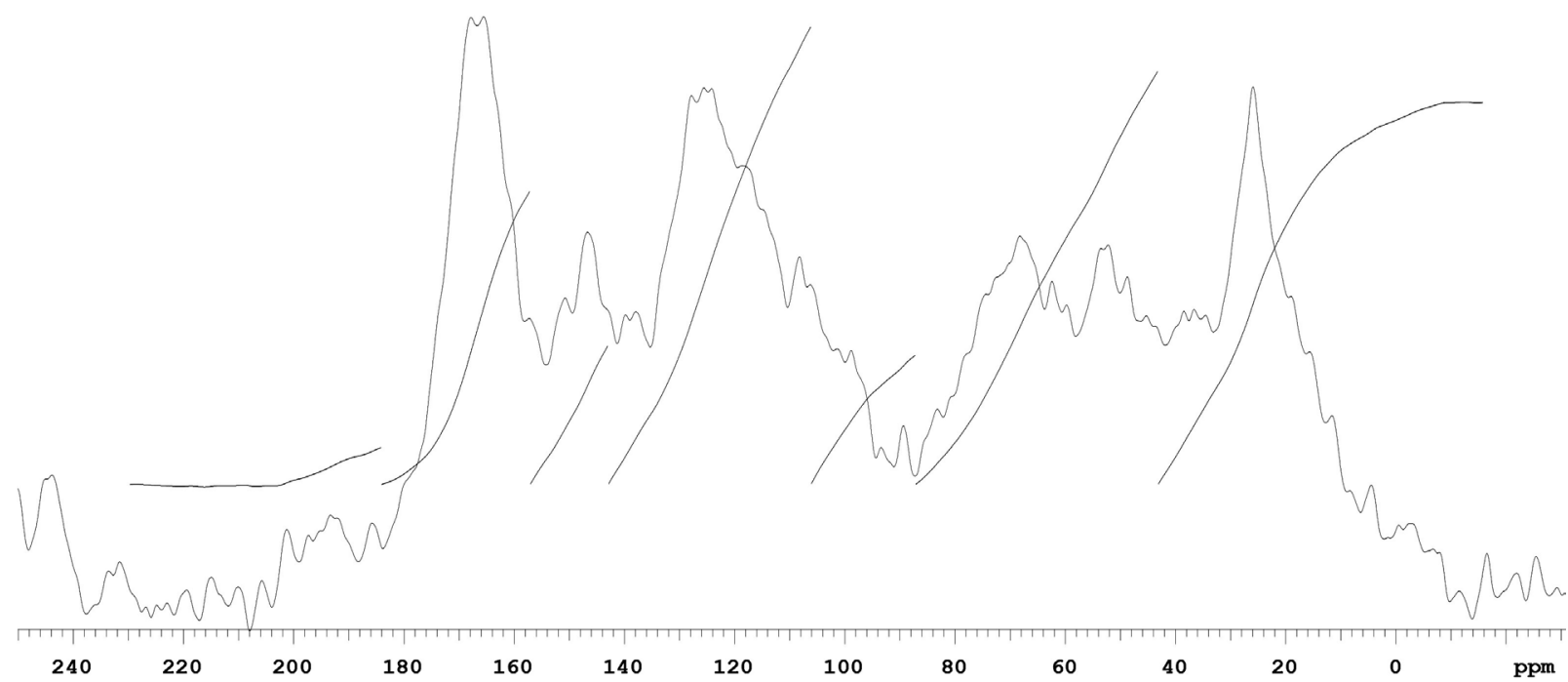

Figure $1 .{ }^{13} \mathrm{C}$ NMR spectra of alginate HA A

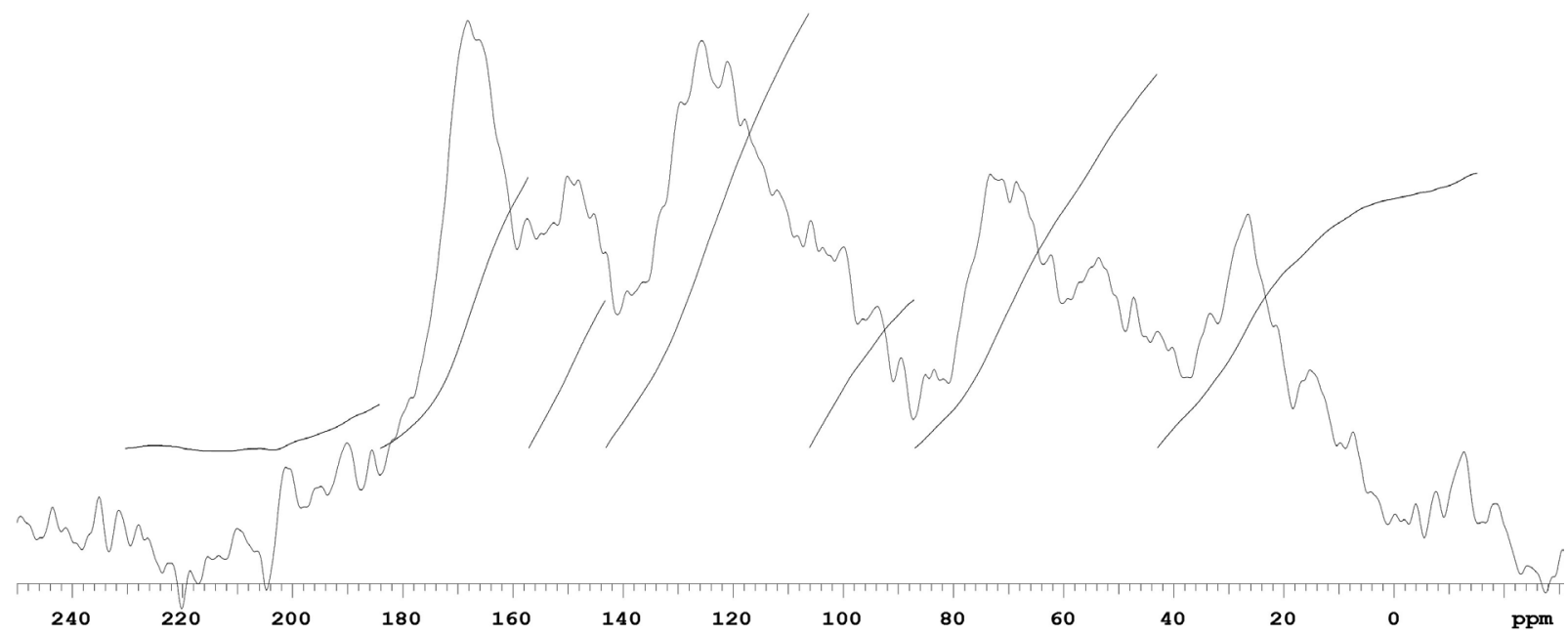

Figure $2 .{ }^{13} \mathrm{C}$ NMR spectra of alginate HA B 
Ono et al. 2009). The higher values of $\alpha$ are characterised for more stable structure of HA. As it can be seen from Table 5 , values of aromaticity degree are very low, the first of all in HA B.

Comparison of chemical structure of alginite $H A$ and soil HA

Alginite HA A was taken for comparison of chemical structure of alginite and soil HA because for the isolation of soil HA and alginite HA A, the same isolation method (modified international IHSS method) was applied. Soil HA were isolated from different soil types and different land use. Haplic Cambisol 1 and Andic Cambisol are forest soils, Haplic Chernozem is typical agriculture arable soil and Haplic Cambisol 2 is pasture. The lowest concentration of organic carbon was found in Haplic-Chernozem and

$\mathrm{T}$ a

Relative integral intensities $[\mathrm{ppm}]$ and basic parameters calculated from ${ }^{13} \mathrm{C}$ NMR spectra of alginite $\mathrm{HA}$

\begin{tabular}{|l|r|r|r|r|r|r|r|r|r|r|}
\hline Alginite HA & $\begin{array}{c}230-184 \\
{[\mathrm{ppm}]}\end{array}$ & $\begin{array}{c}184-157 \\
{[\mathrm{ppm}]}\end{array}$ & $\begin{array}{c}157-143 \\
{[\mathrm{ppm}]}\end{array}$ & $\begin{array}{c}143-106 \\
{[\mathrm{ppm}]}\end{array}$ & $\begin{array}{c}108-87 \\
{[\mathrm{ppm}]}\end{array}$ & $\begin{array}{c}87-43 \\
{[\mathrm{ppm}]}\end{array}$ & $\begin{array}{c}43-15 \\
{[\mathrm{ppm}]}\end{array}$ & $\begin{array}{c}\mathrm{C}_{\text {aliph }} \\
{[\%]}\end{array}$ & $\begin{array}{c}\mathrm{C}_{\text {ar }} \\
{[\%]}\end{array}$ & $\begin{array}{c}\alpha \\
{[\%]}\end{array}$ \\
\hline HA A & 1.95 & 8.12 & 3.96 & 17.88 & 9.27 & 39.27 & 18.95 & 67.49 & 21.84 & 24.5 \\
HA B & 2.24 & 8.79 & 1.15 & 10.11 & 11.79 & 50.81 & 15.11 & 77.71 & 11.26 & 12.7 \\
\hline
\end{tabular}

HA A - alginite humic acids isolated by method A; HA B - alginite humic acids isolated by method B;

$\mathrm{C}_{\text {aliph }}$ - aliphatic carbon; $\mathrm{C}_{\mathrm{ar}}-$ aromatic carbon; $\alpha$ - degree of aromaticity

$\mathrm{T}$ a

Soil types, total organic carbon (TOC) in alginite and soils, amount of isolated HA [\%], moisture and ash content of HA

\begin{tabular}{|l|r|c|c|c|c|}
\hline Soil type/material & $\begin{array}{r}\text { TOC } \\
{[\%]}\end{array}$ & HA & $\begin{array}{c}\text { HA } \\
{[\%]}\end{array}$ & $\begin{array}{c}\text { Moisture } \\
{[\%]}\end{array}$ & $\begin{array}{c}\text { Ash } \\
{[\%]}\end{array}$ \\
\hline Alginite Pinciná & 7.3 & Alginite HA & 0.13 & 9.4 & 0.08 \\
Haplic Cambisol 1 & 7.5 & Soil HA 1 & 0.97 & 9.8 & 0.90 \\
Andic Cambisol & 18.5 & Soil HA 2 & 0.92 & 11.0 & 0.54 \\
Haplic Chernozem & 2.1 & Soil HA 3 & 0.41 & 11.7 & 0.78 \\
Haplic Cambisol 2 & 5.2 & Soil HA 4 & 1.03 & 9.7 & 1.06 \\
\hline
\end{tabular}

TOC - total organic carbon; HA - humic acids

T a

Elemental composition [atomic\%] and atomic $\mathrm{H} / \mathrm{C}$ and $\mathrm{C} / \mathrm{N}$ ratios of $\mathrm{HA}$

\begin{tabular}{|l|c|c|c|c|c|c|}
\hline Samples & $\mathrm{C}$ & $\mathrm{H}$ & $\mathrm{N}$ & $\mathrm{O}$ & $\mathrm{H} / \mathrm{C}$ & $\mathrm{C} / \mathrm{N}$ \\
\hline Alginite HA & 35.4 & 42.8 & 1.9 & 20.0 & 1.21 & 18.63 \\
Soil HA 1 & 40.6 & 38.7 & 3.2 & 17.6 & 0.94 & 12.69 \\
Soil HA 2 & 42.1 & 35.9 & 2.8 & 19.2 & 0.85 & 15.04 \\
Soil HA 3 & 49.1 & 28.1 & 3.8 & 18.6 & 0.58 & 12.92 \\
Soil HA 4 & 38.2 & 40.7 & 3.5 & 17.5 & 1.07 & 10.91 \\
\hline
\end{tabular}

$\mathrm{C}$ - carbon; $\mathrm{H}$ - hydrogen; $\mathrm{N}$ - nitrogen; $\mathrm{O}$ - oxygen 
the highest concentration of organic carbon was detected in forest Andic Cambisol (Table 6).

Alginite has the concentration of organic carbon same as that of forest soil (Tables 1 and 6); however, amount of HA isolated from alginite (alginite HA A, Table 6) was more than seven times lower in comparison with HA isolated from Haplic Cambisol (soil HA1) (Table 6). Agriculture soils, mainly intensively arable Haplic Chernozem, has more than three times lower organic carbon content (Table 6) in comparison with alginite sample; however the amount of HA isolated from this soil type (soil HA 3 ) was more than three times higher (Table 6).

The difference in the amount of HA in alginite and soil samples can be explained by the difference in the origin of organic matter in alginite and soil samples. Alginite is fossil biomass with high content of organic matter comes from mainly yellow-green algae Botryococcus braunii Kunz. Its high hydrocarbon potential and immature kerogen content correspond to the initial stage of the production of petroleum hydrocarbons (Vass et al.1997)

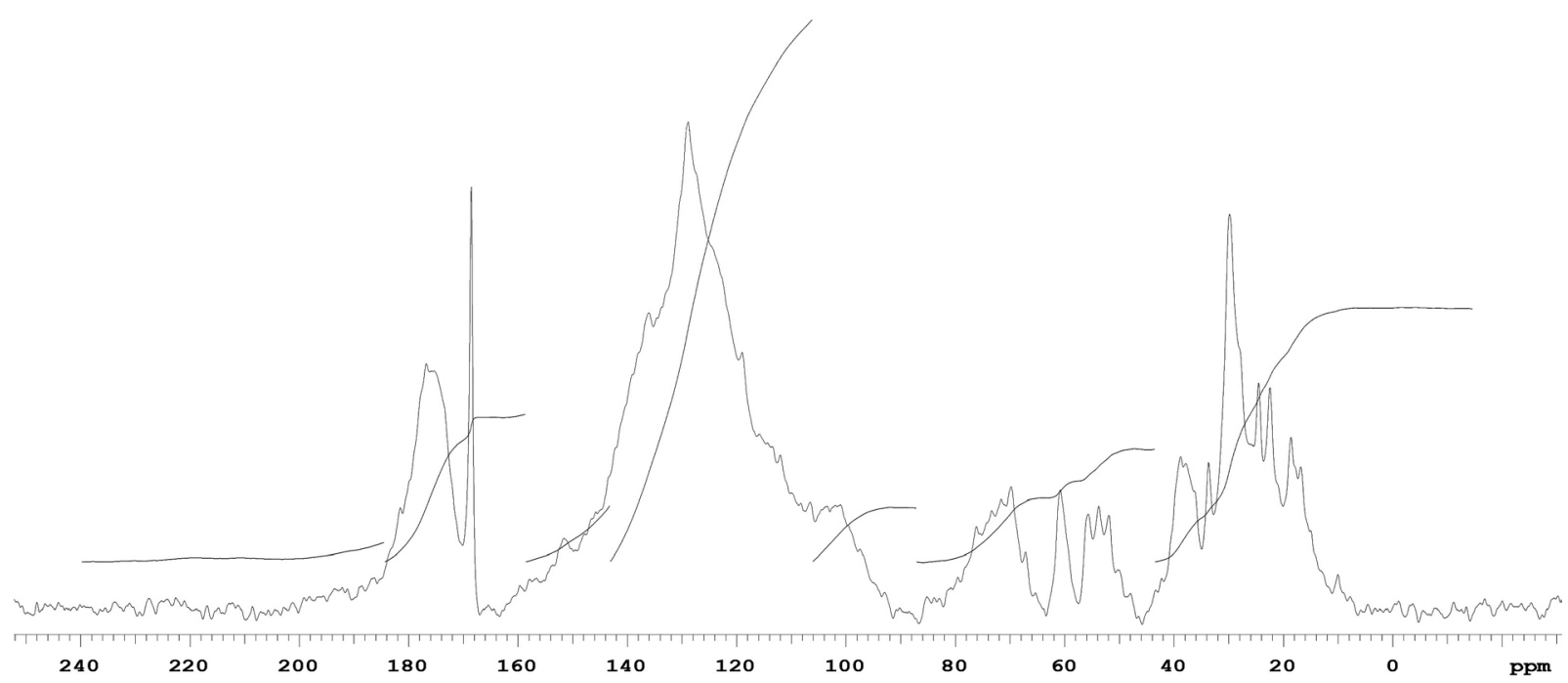

Figure $3 .{ }^{13} \mathrm{C}$ NMR spectra of soil HA 1

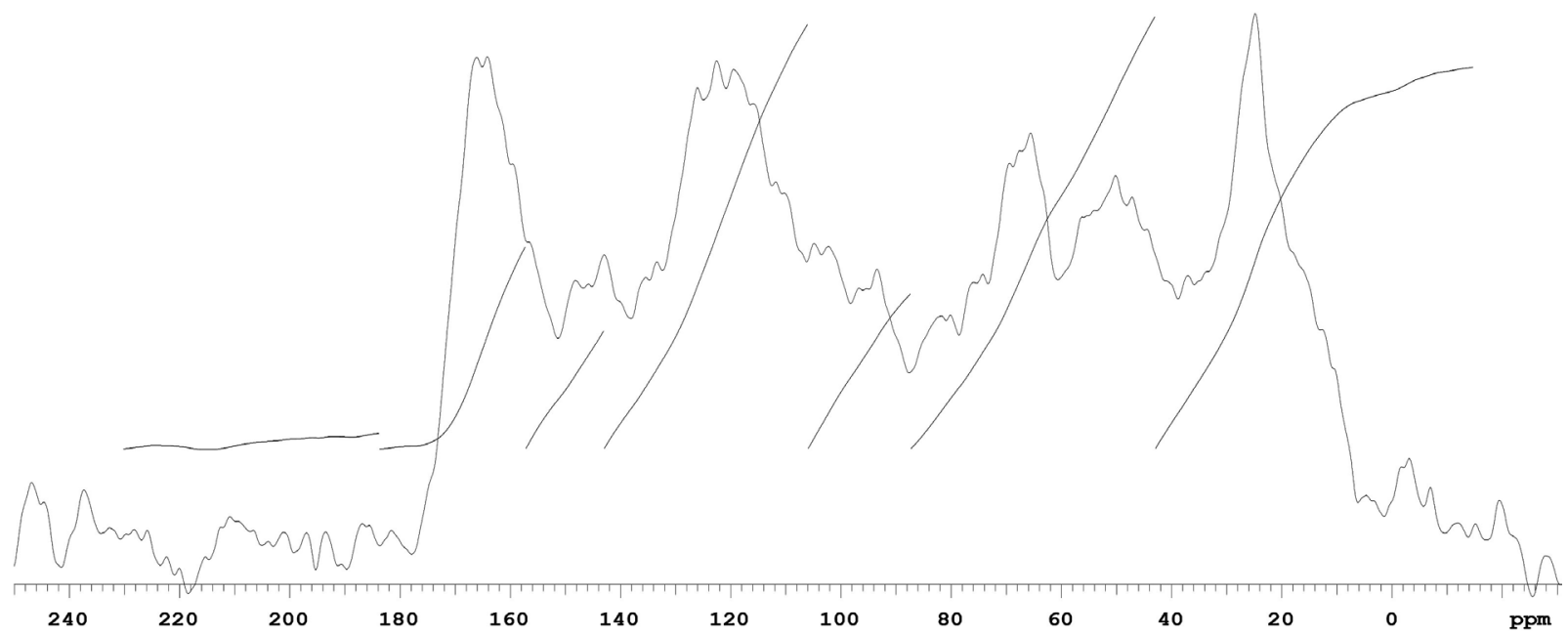

Figure $4 .{ }^{13} \mathrm{C}$ NMR spectra of soil HA 2 
Source of soil organic matter is lignin and cellulose of higher plants (Madronova et al. 2011; Tan 2014). Moisture and ash content in all observed humic acids are relatively same, as they were isolated in the same way (Table 6).

Values of elemental composition of HAs are quite different (Table 7); however, they are typical for soil HA. As reported by Tan (2014), the amount of carbon in atomic percentage in soils is in the range $35-48 \%$ and that of hydrogen is $30-43 \%$. Similar range of C and $\mathrm{H}$ was found also in Slovak soils (Barančíková 2014). The highest concentration of organic carbon was found in HA isolated from Haplic Chernozem (soil HA 3), and the lowest concentration of $\mathrm{C}$ was detected in alginite $\mathrm{HA}$; contrastingly, the highest $\mathrm{H}$ content was detected in alginite HA, and the lowest $\mathrm{H}$ content was detected in Chernozem HA (Table 7). In alginite $\mathrm{HA}$, the lowest $\mathrm{N}$ content and the highest

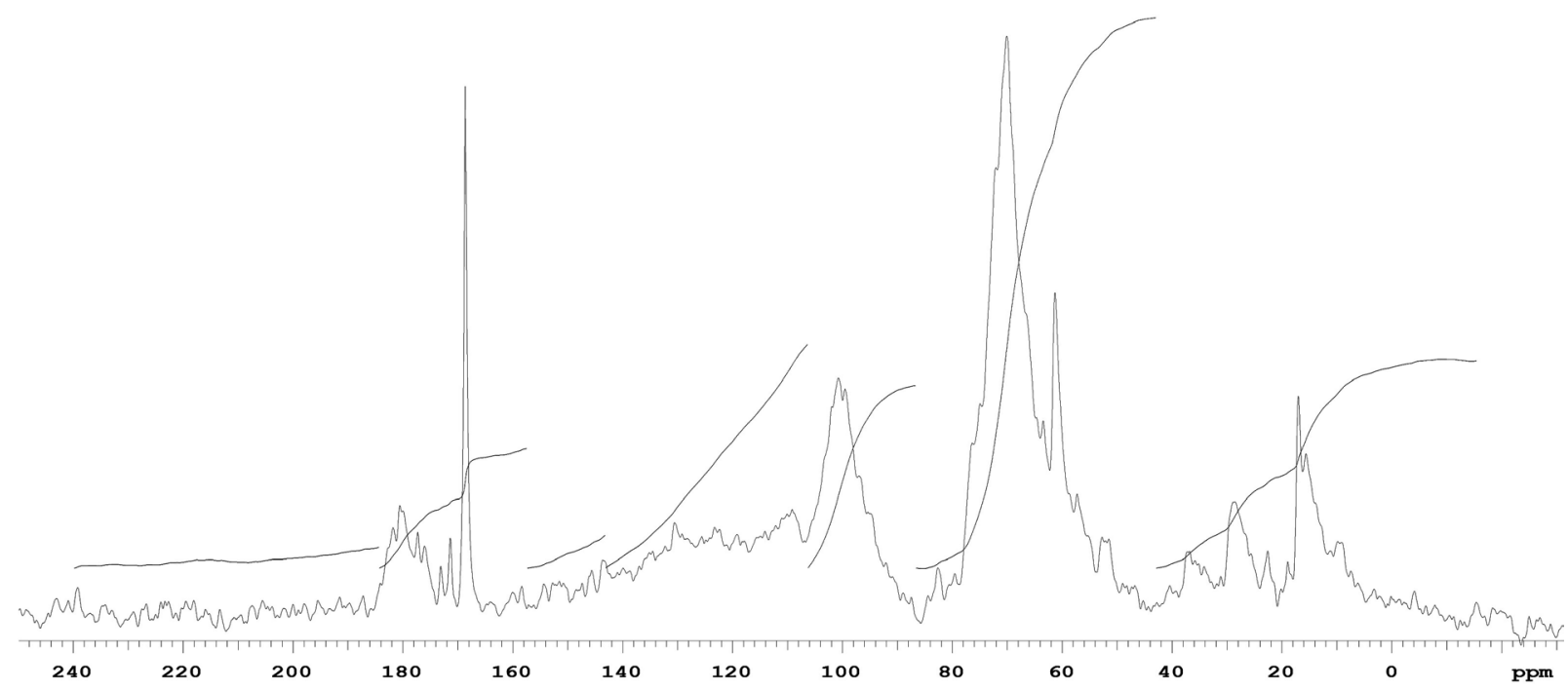

Figure $5 .{ }^{13} \mathrm{C}$ NMR spectra of soil HA 3

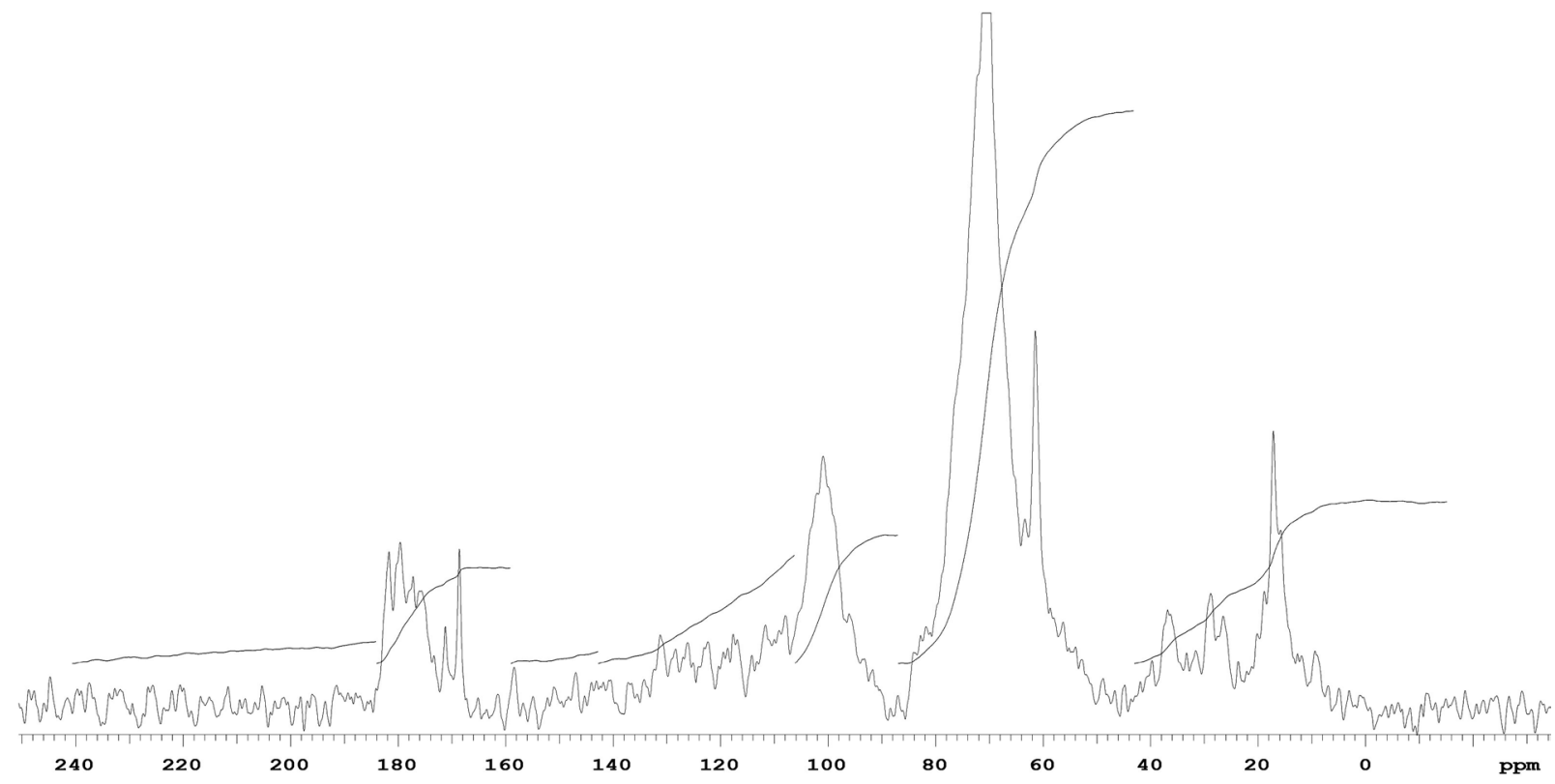

Figure $6 .{ }^{13} \mathrm{C}$ NMR spectra of soil HA 4 
O content in comparison with soil HA was also detected (Table 7).

As it was mentioned earlier, atomic percentage and atomic ratios are useful as guider in the identification of different types of HA (Sterlink 1985). It is generally believed that the $\mathrm{C} / \mathrm{N}$ ratio will decrease with increased rate of degree of humification, and $\mathrm{C} / \mathrm{N}$ ratios between 10 and 15 are often considered to be the characteristic of well-developed HA (Tan 2014).

As can be seen in Table 7, all soil HA are well developed because their $\mathrm{C} / \mathrm{N}$ ratios vary from 10 to 15 ; however, $\mathrm{C} / \mathrm{N}$ ratio of alginite $\mathrm{HA}$ is greater than 18. Humification degree can also be judged according the $\mathrm{H} / \mathrm{C}$ value. $\mathrm{H} / \mathrm{C}$ atomic ratio is commonly used to indicate the maturity of humic substances (Sanchez et al. 2002). A low H/C ratio is characteristic of a complex humic substances structure with aromatic character as a consequence of polymerisation (humification) reactions. As it was mentioned earlier, Debska et al. (2009) and Rossell et al. (1989) reported that the smaller the $\mathrm{H} / \mathrm{C}$ ratio, the bigger will be the degree of humification. According to this, amongst soil HA, Haplic Chernozem HA has the highest degree of humification and Cambisol HA on pasture the lowest (Table 7). Substantially higher $\mathrm{H} / \mathrm{C}$ ratio in alginite HA than soil HAs (Table 7) indicates the lowest degree of humification of alginate humic organic matter compared to that of soil HA.

Considerable differences between humic acids isolated from different soil types and alginite HA can be seen also from ${ }^{13} \mathrm{C}$ NMR spectra. ${ }^{13} \mathrm{C}$ NMR technique allows to clarify in detail the chemical structure of heterogeneous compounds. Spectral method of ${ }^{13} \mathrm{C}$ NMR can also detect the variation in chemical structure of HA of various soil types (Buurman et al. 2009), in one soil type at the change of soil management (Mao et al. 2008) or in different origin (Tan 2014). The analysis with ${ }^{13} \mathrm{C}$ NMR spectroscopy is capable of measuring the distribution of $\mathrm{C}$ in the various types of compounds, and this information can be used in structural analysis and in differentiating the different types of humic matter (Tan 2014). Significant predominance of aliphatic structures $(\mathrm{C})$ over condensed aromatics cores $\left(\mathrm{C}_{\mathrm{ar}}\right)$ in the alginite $\mathrm{HA}$ structure is evident also from ${ }^{13} \mathrm{C}$ NMR spectra (Figures 1 and 3-6, Table 8).

Strong signal at $75 \mathrm{ppm}$ typical for carbohydrate carbon (Schnitzer et al. 2006) and much less marked aromatic regions (143-106 ppm) are the dominant features of alginite $\mathrm{HA}$ in ${ }^{13} \mathrm{C}$ NMR spectra (Figure 1). Higher content of aromatic carbon (C) and lower amount of aliphatic carbon (C) are characteristic of soil HA (Figures 3-6, Table 8), however, among them are significant differences.

Soil HA isolated from Haplic Chernozem (soil HA 3) has strong signal between 105 and 165 ppm chemical shift for aromatic carbon. In Haplic Cambisol HA (soil HA 1 and 6), aliphatic structures predominate, and carbon peak of methoxyl structure at $56 \mathrm{ppm}$ and O-alkyl peak at $43-87 \mathrm{ppm}$ can be recognised in ${ }^{13} \mathrm{C}$ NMR spectra (Gonzales-Perez et al. 2008). In Cambisol HA, peak at 75 ppm typical for carbohydrates (Preston et al. 1994; Schnitzer et al. 2006) (Figures 3 and 6) and peak at $104 \mathrm{ppm}$ specific for di-O-alkyl carbon involving anomeric carbon of carbohydrates (Preston et al. 1994) can

T a b 1 e 8

Relative integral intensities [ppm] and basic parameters calculated from ${ }^{13} \mathrm{C}$ NMR spectra of alginite and soil HA

\begin{tabular}{|l|c|c|c|c|c|c|c|c|c|c|}
\hline Sample & $\begin{array}{c}230-184 \\
{[\mathrm{ppm}]}\end{array}$ & $\begin{array}{c}184-157 \\
{[\mathrm{ppm}]}\end{array}$ & $\begin{array}{c}157-143 \\
{[\mathrm{ppm}]}\end{array}$ & $\begin{array}{c}143-106 \\
{[\mathrm{ppm}]}\end{array}$ & $\begin{array}{c}108-87 \\
{[\mathrm{ppm}]}\end{array}$ & $\begin{array}{c}87-43 \\
{[\mathrm{ppm}]}\end{array}$ & $\begin{array}{c}43-15 \\
{[\mathrm{ppm}]}\end{array}$ & $\begin{array}{c}\mathrm{C}_{\text {aliph }} \\
{[\%]}\end{array}$ & $\begin{array}{c}\mathrm{C}_{\mathrm{ar}} \\
{[\%]}\end{array}$ & $\begin{array}{c}\alpha \\
{[\%]}\end{array}$ \\
\hline Alginite HA & 1.95 & 8.12 & 3.96 & 17.88 & 9.27 & 39.27 & 18.95 & 67.5 & 21.8 & 24.4 \\
Soil HA 1 & 2.00 & 15.85 & 7.52 & 24.73 & 6.97 & 22.32 & 20.61 & 49.9 & 32.3 & 39.3 \\
Soil HA 2 & 2.59 & 16.01 & 8.75 & 25.66 & 8.76 & 22.04 & 16.19 & 47.0 & 34.4 & 42.3 \\
Soil HA 3 & 2.90 & 11.80 & 6.20 & 39.10 & 4.80 & 12.50 & 22.80 & 40.1 & 45.3 & 53.0 \\
Soil HA 4 & 0.90 & 11.71 & 6.86 & 24.54 & 8.96 & 24.99 & 22.04 & 56.0 & 31.4 & 35.9 \\
\hline
\end{tabular}

$\mathrm{C}_{\text {aliph }}-$ aliphatic carbon; $\mathrm{C}_{\mathrm{ar}}-$ aromatic carbon; $\alpha$ - degree of aromaticity 
also be found (Figure 3). Results show that the content of aromatic carbon was decreasing in the following order: Haplic Chernozem HA > Andic Cambisol HA $>$ Haplic Cambisol HA $>$ alginite HA.

The dominant aromatic structure and the lowest amount of aliphatic carbon resulted in the highest degree of aromaticity $(\alpha)$ were found in soil HA 3 (Figure 4, Table 8), and it is typical for stable and mature organic matter of Haplic Chernozem. The lowest aromatic and the highest aliphatic carbon content were found in alginite HA (Figure 1, Table 8). As it was mentioned earlier, precursors of alginite HA are marine organic materials that come from algae (Vass et al. 1997) and not higher plants as in soil HA (Madronova et al. 2011).

\section{CONCLUSIONS}

Alginite is very useful in agricultural utilisation because of its positive influence on physical and chemical properties of soil. Because of the difference in origin of organic matter in alginite and soil, this article focuses in differences in chemical structure of alginite and soil HA. On the basis of obtained results, it can be concluded that the differences between HA isolated from soil and alginite HA are significant. Alginite HA isolated using two different procedures are characteristic of predominance of aliphatic carbon and very low degree of aromaticity mainly in alginite HA B isolated with simplified extraction method suited for large volumes of HA. ${ }^{13} \mathrm{C}$ NMR spectra also show differences between the soil HA isolated from different soil types; however, all soil HA have higher degree of aromaticity characterised by higher degree of humification and higher mature of soil organic matter compare to alginate HA. The differences in chemical structure of soil HA and alginite HA can be explained by the differences in origin of organic material in soils and alginite. In soil HA, type III kerogen originated from cellulose and lignin is dominant, and type II kerogen originated from algae is a characteristic of alginite HA.

Acknowledgements. This work was supported by the Slovak Research and Development Agency under the contract No. APVV-0199-11 and APVV14-0087.

\section{REFERENCES}

BARANČÍKOVÁ G. 2008. Application of Nuclear Magnetic Resonance Spectroscopy in Soil Organic Matter. In Chemické Listy, vol. 102, no.12, pp. 1100-1106.

BARANČÍKOVÁ, G. - BEZÁK, P. - DODOK, R. CHLPÍK, J. - KOBZA, J. - MAKOVNÍKOVÁ, J. PÍŠ, V. 2011. Methods of determining indicators of agrochemical soil properties. In HRIVŇÁKOVÁ, K. MAKOVNÍKOVÁ, J. (Eds.) Integrated procedures of soil analyse. Bratislava : VUPOP, pp. 52-115. ISBN 978-80-89128-89-1

BARANČÍKOVÁ, G. 2014. Monitoring of quantitative and qualitative composition of soil organic mater. In KOBZA, J. (Ed.) Soil monitoring of the Slovak Republic. Actual state and development og monitoring soil properties as the basis for their protection and land use (the period 2007-2012). Bratislava : NPPC, VUPOP, pp. 53-89. ISBN 978-80-8163-004-0

BELÁČEK, B. 2006. Možnosti využitia novej suroviny - alginitu $v$ lesnom hospodárstve [Possibility of using new material - alginate in forestry] : PhD Thesis, Zvolen : Technical University of Zvolen, p. 108.

BUURMAN, P. - NIEROP, K.G.J. - KAA, L.J. - SENESI, N. 2009. Analytical pyrolysis and thermally assisted hydrolysis and methylation of EUROSOIL humic acid samples - A key to their source. In Geoderma, vol. 150, no. 1-2, pp. 10-22. http://dx.doi.org/10.1016/j. geoderma.2008.12.012

DEBSKA, B. - SOMBATHOVA, N. - BANACH-SZOTT, M. 2009. Properties of humic acids of soil under different management regimes. In Polish Journal of Soil Science, vol. 42, pp. 131-138.

ENEV, V. - POSPÍŠILOVÁ, L. - KLUČÁKOVÁ, M. LIPTAJ, T. - DOSKOČIL, L. 2014. Spectral characterization of selected humic substances. In Soil and Water Research, vol. 9, pp. 9-17.

GONZÁLES-PÉREZ, M. - TORRADO, V.P. - COLNAGO, L.A. - MARTIN-NETO, L. - OTERO, X.L. - MILORI, D.M.B.P. - GOMES, F.H. 2008. ${ }^{13} \mathrm{C}$ NMR and FTIR spectroscopy characterization of humic acids in spodosols under tropical rain forest in southeastern Brazil. In Geoderma, vol. 146, pp.425-433. http://dx.doi.org/10.1016/j.geoderma.2008.06.018

HAYES, M.B.H. 1985. Extraction of humic substances from soils. In AIKEN, G.R. - WERSHAW, R.L. - McKNight, D.M. - McCARTHY, P. (Eds.) Humic substances in soil, sediment and water. New York : John Wiley, N.Y., pp. 329-362.

KULICH, J. - VALKO, J. - OBERNAUER, D. 2001. Perspektíva využitia alginitu vo výžive rastlín [Perspective of exploatation of alginite in plant nutrition]. In Journal of Central European Agriculture, vol. 2, pp.199-206.

LITAVEC, T. - BARANČÍKOVÁ, G. 2013. Základná charakteristika alginitu (Basic characteristic of alginit). In HOUŠKOVÁ, B. (Ed.) Vedecké práce VÚPOP, vol. 35, Bratislava : VÚPOP, pp. 97-106. ISBN 978-80-8163-003-3.

MADRONOVA, L. 2011. Humic substances from raw materials of the Czech Republic. New York : Nova 
Science Publishers, Inc., pp. 123. ISBN 978-1-61668965-0.

MALCOLM, M.L. 1990. The uniqueness of humic substances in each of soil stream and marine environments. In Analytica Chimica Acta, vol. 232, pp.19-30.

MAO, J. - OLK, D.C. - FANG, X. - HE, Z. - SCHMIDTROHR, K. 2008. Influence of animal manure applicatioín on the chemical structures of soil organic mater as investigated by advanced solid-state NMR and Ft-IR spectroscopy. In Geoderma, vol. 146, no. 1-2, pp. 353-362. http://dx.doi.org/10.1016/j.geoderma.2008.06.003

ONO, K. - HIRAI, K.B. - MORITA, S. - OHSE, K. HIRADATE, S. 2009. Organic carbon accumulation processes on a forest floor during an early humification stage in a temperate deciduous forest in Japan: Evaluations of chemical composition changes by ${ }^{13} \mathrm{C}$ NMR and their decomposition rates from litterbag experiment. In Geoderma, vol. 151, pp. 351-356. http:// dx.doi.org/10.1016/j.geoderma.2009.05.001

ORLOV, D.S 1985. Humus acids of soils. Moscow : University Press, Moscow, pp. 334.

ORLOV, D.S. - GRIŠINA, L.A. 1981. Praktikum po chimiji gumusa [Practical training of humus chemitry]. Moscow : University Press, Moscow, pp. 270.

PRESTON, C.M. - NEWMAN, R.H. - ROTHER, P. 1994. Using ${ }^{13} \mathrm{C}$ CPMAS NMR to assess effects of cultivation on the organic matter of particle size fractions in a grassland soil. In Soil Science, vol. 157, no. 1, pp. 26-35.

PRESTON, C.M. 1996. Application of NMR to soil organic matter analysis: History and prospects. In Soil Science, vol. 161, no. 3, pp. 144-166.

ROSSELL, R.A. - ANDRIULO, A.E. - SCHNITZER, M. - CRESPO, M.B. - MIGLIERINA, A.M 1989. Humic acids properties on an Argiudoll soil under two tillage systems. In Science of Total Environment, vol. 81/82, pp. 391-400.

SANCHEZ-MONEDERO, M.A. - MONDINI, C. - DE NOBILI, M. - LEIRA, I. - ROIG, A. 2002. Land application of biosolids: Soil response to difference stabilization degree of the traced organic matter. In Waste Management, vol. 24, no. 4, pp. 325-332. http://dx.doi.org/10.1016/j.wasman.2003.08.006

SCHNITZER, M. - MCARTHUR, D.F.E. - SCHULTEN, H-R. - KOZAK, L.M. - HUANG, P.M. 2006. Longterm cultivation effects on the quantity and quality of organic matter in selected Canadian prairie soils. In Geoderma, vol. 130, no.1-2, pp. 141-156. http:// dx.doi.org/10.1016/j.geoderma.2005.01.021

SOLTI, G. 1987. Az Alginit [The alginite]. Budapest : A Magyar Állami Földtani Intézet Alkalmi Kiadványa, $40 \mathrm{p}$.

STEELING, C. 1985. Implications of elemental characteristics of humic substances. In AIKEN, G.R. - MCKNIGHT, M. - WERSHAW, R.L. - MACCARTHY, P. (Eds) Humic Substances in Soil, Sediment, and Water. Geochemistry, Isolation, and Characterization. New York: Wiley-Interscience, pp. 457-476.

TAN, H.K. 2014. Humic mater in soil and the environment. Boca Raton : CRC Press, pp. 461, ISBN 978-14822-3445-4.

VASS, D. - KONEČNÝ, V. - ELEČKO, M. - MILIČKA, J. - SNOPKOVÁ, P. - ŠUCHA, V. - KOZAČ, J. - ŠKRABANA, R. 1997. Alginit - nový zdroj Slovenského nerudného surovinového potenciálu (ložisko Pinciná) [Alginit - a new source of Slovak non ore resource potential (bearing Pincina)]. In Mineralia Slovaca, vol. 29, pp. 1-39.

Received: November 14, 2016 